This is a self-archived version of an original article. This version may differ from the original in pagination and typographic details.

Author(s): Palonen, Kari

Title: Rhetoric of academic applications : Perspectives from Quentin Skinner's Forensic Shakespeare

Year: 2021

Version: Accepted version (Final draft)

Copyright: (C) 2019 Informa UK Limited, trading as Taylor \& Francis Group

Rights: In Copyright

Rights url: http://rightsstatements.org/page//nC/1.0/?language=en

Please cite the original version:

Palonen, K. (2021). Rhetoric of academic applications : Perspectives from Quentin Skinner's Forensic Shakespeare. Global Intellectual History, 6(1), 5-13.

https://doi.org/10.1080/23801883.2019.1657638 


\section{Rhetoric of academic applications: perspectives from Quentin Skinner's Forensic Shakespeare}

Kari Palonen

University of Jyväskylä

abstract

The tools of classical and Renaissance rhetoric that Quentin Skinner uses in his Forensic Shakespeare (2014) are here applied to a contemporary context. Skinner's discussion might have a fairly direct value for a genre of writing that most academics today must master, namely the rhetoric of applications. They have been seldom discussed from a rhetorical perspective, although knowledge of rhetoric is highly valuable for applicants, evaluators and those deciding between applications. Skinner's book contains both advices for applicants and discussions on both the criteria of application and the possibilities of their revisions in case of innovative applications.

keywords. Academic applications, application rhetoric, Forensic Shakespeare, Quentin Skinner, research funding, rhetorical genres

The topic of this essay is the rhetoric of academic applications - for university positions, research projects or scholarships. In present-day academia the justification of one's research, peer evaluation, recommendations for younger scholars' applications as well as acting as referee, evaluator or decision-maker for funding and positions are everyday concerns.

The rhetoric of applications is a thoroughly political activity, in the elementary Weberian sense of politics as Streben nach Machtanteil und Beeinflussung der Machtverteilung. ${ }^{1}$ The passed applications will provide new Machtchancen for the applicants and their type of research, depending on those who decide on the applications. 


\section{Academic applications among the rhetorical genres}

It is not easy to situate the rhetorical genre of academic applications into the Aristotelian division of genres. ${ }^{2}$ Are the applications judged according to the quality of the presentation (epideictic), the records of the author (forensic) or the plan for action (deliberative)? Who judges the applications - a critic, (epideictic) a judge or a jury (forensic); or a multi-member peer audience (deliberative)? Is the application comparable to an artefact (epideictic), a plea of the defendant (forensic) or a petition of citizens to the parliament (deliberative)? All three genres seem to be relevant and mark an interdisciplinary element.

For the epideictic criterion of praise and blame art criticism is the paradigm. It is important to write pleasant, beautiful, nice and clever applications. The forensic criterion judges the past scholarly records of the applicants and the relation of the new work to it. The deliberative point consists in evaluating the projected plan to complete the applied research, its scholarly contribution, realisability and significance. The question is, how do the evaluators themselves see their relationship to the rhetorical genres.

To discuss the rhetoric of application I turn to Quentin Skinner's Forensic Shakespeare, although my discussion does not prioritise the forensic genre. The point is rather to understand the opposed requirements that should be recognised in composing and evaluating the applications. Forensic Shakespeare forms a sequel to Skinner's Reason and Rhetoric in the Philosophy of Hobbes as a conceptual inquiry of the rhetorical culture of the English Renaissance. Skinner offers us a focused study of one prominent aspect of this culture: William Shakespeare's 'forensic plays'.

I shall speculate how the rhetorical tools that Skinner detects in Shakespeare's plays could be transferred to the practice of application rhetoric. I will offer a Weberian-style thought experiment of transferring Skinner's discussion to the contemporary academic

rhetoric. For Weber it is parliamentary rather than the forensic rhetoric that is the model for scholarly activities. ${ }^{3}$

The following discussing will take up a selection of the topoi discussed by Skinner. I shall take up the rhetoric of beginning, the ethos of the applicant and the types of causes to be defended as well as the types of disputes. In the conclusions I shall compare the rhetorical genres and opt for understanding applications as petitions addressed to a parliamentary-type committee. 


\section{The ethos of the applicant}

An applicant should know that the beginning is crucial for the readers. Skinner puts the point: 'The prohoemium must aim to establish our ethos or character, and in a such way as to render the judge attentive (attentus), responsive (docile), and above all welldisposed (benevolus) to our side of the case.' ${ }^{4}$ An inherent part of the epideictic rhetoric is that the author must 'establish' one's ethos in order to make the application plausible. Skinner refers on the quality criteria of judging which might be turned against each other.

When the applications must be compared with each other, attention counts. 'To win attention, the rhetoricians lay down, we must speak of new and unknown events', Skinner writes. ${ }^{5}$ To achieve this, the application must stand apart from others with a personal profile in topic, perspective, style of argumentation or the art of contribution. Regarding 'responsiveness', Skinner quotes Thomas Wilson's Arte of Rhetorique: 'teachyng the hearers what the matter is' in order to 'make theim understande the matter easily. ${ }^{6}$ The applicant has to adapt the argumentation to the expectations of the audience and to retain one's own distinctive point of view. This requires the ability to present one's point in a language intelligible to non-specialists. The academic applicants must further estimate the expectations of their evaluators, even when they don't know who they will be. Shall one adapt to the expected audience or assume that the evaluators would be open to unconventional views?

The reviewers of applications might be 'well-disposed', at least curious to learn something new, but no one should expect 'benevolence' from them. The initial curiosity might be opposed by reservations against newcomers or suspicion against competitors among the established scholars. The parliamentary-type procedure of a fair debate pro et contra would put obstacles to such a priori prejudices.

Building one's own academic ethos, that is, a distinct intellectual profile, does never guarantee any success and sometimes provokes a fierce opposition. Still such profile would be mark the person as 'somebody', whereas an opportunistic adaptation to specific expectations of the target audience would also easily raise doubts among the evaluators. Both provocative and adaptive strategies as well as middle courses do have their risks that are difficult to estimate in advance.

\section{Types of cases and alternative ways of beginning}


When Skinner discusses the rhetorical alternatives to begin a speech, he summarises the ancient rhetoricians' view in four types causes to defend: 'the causa honesta, the causa turpis, the causa admirabilis, and the type that Cicero and Quintilian describe as anceps, that is, partly turpis and partly honesta in character.'7

The translations of these Latin terms are not obvious. Turpis refers to 'dishonest', 'foul, a usage that gave rise to the phrase "foul play" to describe serious crimes, especially murder'. The vernacular rhetoricians' translations of honestus included such terms as 'laudable, virtuous' or 'good, kinde, noble, honourable, of good behaviour, well-mannered'. For Quintilian admirabilis means 'out of line with the general opinion of men' (prater opinionem hominum constitutum), and 'To speak in Shakespearean England of a causa admirabilis was thus to refer to a cause that was felt in some way to be strange or astonishing, a source of wonderment." 8

Making one's application to appear as laudable as possible is obvious. For the evaluators the self-praise of the applicants soon becomes annoying. How to present one's own application as laudable in a way that is not too declamatory? To detect something 'dishonest' in the applications in the forensic sense of violation of accepted rules is an easy reason to disqualify them. To extenuate a foul in the application as marginal or irrelevant for the case would require a paradiastolic move $\mathrm{e}^{9}$ from the evaluators. Parliamentary-type evaluators might be more willing to reconsidering the rules themselves or revaluate causa turpis.

Good applications must contain something of causa admirabilis. For a good research 'strange' or 'astonishing' are attributes of praise and the applicant must avoid the impression of doing 'normal science'. The critic- and parliamentarian-types of evaluators would likely be more receptive for 'strange' applications than the jury member type. Like backbenchers' motions to parliament, the applications must justify their 'paradiastolic' inversions, revaluing the vices and virtues in a persuasive manner. Skinner distinguishes between 'open' and 'insinuative' beginnings of a speech. The open beginning states the principium, in Cicero's terms 'a clear and plain speech aiming to win from your hearers their goodwill, responsiveness and attention'. In contrast, 'insinuatio is a speech that manages by means of dissimulation and indirection to worm it subtly into the mind of your audience.' ${ }^{10}$ Skinner further notes: 'Shakespeare was chiefly drawn to dramatizing judicial predicaments in which the speaker is constrained to accept that an insinuative beginning is required.' ${ }^{\text {11 }}$

Open beginnings appear too declarative also for modern scholars: they are more appropriate to ceremonial occasions than as contributions to debates. The applicant has 
a point, if she is able to identify the debates to which a text intends to contribute, the views against which it argues and how it alters the agenda of the debate. Skinner quotes the author of Ad Herennium on bringing the adversaries 'into odium, invidia and contemptio, hatred, unpopularity and contempt. ${ }^{12}$

Insinuative beginnings may refer to the stage of debate when, as Skinner quotes Cicero, 'those who have already spoken may appear to have persuaded our audience', or when one must 'speak at a time when those who ought to be listening to us have already become tired or irritated with the case'. The judge has become 'exhausted or preoccupied' and is 'liable to be alienated or even hostile.' ${ }^{\text {13 }}$ Here the evaluators have in the course of the debate either turned hostile or become too tired to listen to further speeches.

The applications do, furthermore, have their momentum: they have to be written in an appropriate time. In terms of academic career, some applicants may be either 'too early' or 'too late' for the evaluators. This is hard for the unique occasions or to those opened up irregularly, as most professorial appointments. Unlike speeches in parliament or in court, applications are as a rule presented simultaneously. Some applications may appear first as original, but the evaluator soon notes that same concepts or arguments are regularly repeated. An insinuative beginning tries to avoid fashionable jargon repeated as nauseam, or it can pre-empt counter-arguments as irrelevant for one's purposes.

An applicant should not, however, allow polemics to dominate at the cost of thoroughly presenting one's own perspective. Analogies to practices of parliamentary brevity, such speaking only once to one item in the plenum or the time-limits à la clôture, might even be built into the guidelines for application. The person who presents a 'strange' cause 'will be treated as alienus', as Skinner quotes Cicero, or as 'none of ours', in the words of Thomas Cooper. ${ }^{14}$ Shakespeare's figure of Shylock in The Merchant of Venice begins his suit with an open prohoemium and 'seems bent on exactly what plaintiffs in his situation are warned to avoid. ${ }^{15}$ Skinner summarises the point: 'Shylock not only refuses to play the game but exhibits scorn for its rules.' 16

The obvious danger for applications is to be disqualified as 'aliens' to the academic discipline or to the specific competition, in which they participate. They 'play in a wrong league', are pure amateurs, who should know not to enter to the game of professionals, might be typical arguments for exclusion.

A version of insinuation could be to attempt a paradiastolic disregard for the divide between familiar and strange, or by militantly inveighing against the parochialism of the 
insiders, of a discipline for example. The danger of appealing as dilettantish for the critics and even more the forensic argument of against lacking formal academic qualifications provide strong barriers against the revaluation of the alien in academia. The petitions committees of the parliament could be more ready to accept such arguments against the dangers of l'esprit de corps. The plausibility of the insinuative strategy might thus depend on the rhetorical genre within which the evaluators understand themselves to act.

\section{Types of dispute}

A typology of forensic disputes was used in Shakespeare's juridical plays. With Rhetorica ad Herennium, Skinner presents the types of juridical controversy:

When the constitutio is legal 'the controversy will arise out of a text or something stemming from a text'. When the constitutio is conjectural 'the controversy will be about some matter of fact' and more specifically about some mystery surrounding a matter of fact that needs to be resolved. When the constitutio is juridical the facts will not be in dispute, and the controversy will revolve entirely around 'whether something was justly or unjustly done. ${ }^{17}$

Skinner illustrates with Shakespearean examples conflicting interpretations what is the case at stake. It is not always known a priori to which type of dispute a legal case belongs. In the Merchant of Venice, Shylock claims that the dispute between him and Antonio is juridical, whereas Portia insists on its legal character in her argument. ${ }^{18}$ In scholarly matters a question is how far one should comment existing interpretations or rather present a new interpretation of the topic from primary sources and to enter to the dispute in this way. As an insinuative beginning it might be wise to start from an actual controversy but instead of taking stand in favour of one of the disputing parties, the point is rather to alter the research agenda, to make, in a parliamentary sense, an amendment to the debate. In terms of long-term scholarly disputes, a fresh look at the primary sources almost regularly brings new, neglected or underrated aspects to the debate.

The questions of textual criticism are of primary significance. As Skinner notes, when the constitutio is legal, disputes arise on the question 'whether, in the interpretation of a legal document, priority should be given to the spirit or letter of the law. ${ }^{19}$ For the application 'legal' questions of disputing an authoritative interpretation 
of a text might arise for example, when the applicant interprets the guidelines of application in a creative and plausible manner that was, however, not intended by those who wrote the text.

Juridical questions about 'whether something was justly or unjustly done' can, of course, be a topic of applications. Whether the application itself is 'just or unjust' does not arise, except if an evaluator claims that its presuppositions or modes of realisation are somehow unjust, normatively dubious or questionable.

In Shakespeare's plays the conjectural issues are obviously the most interesting ones. Skinner formulates their importance for rhetoricians as follows:

For the rhetoricians there are two as Ad Herennium says, what distinguishes conjectural issues and serves to label them is that 'truth has to be sought by the way of forming a conjecture' and attempting to confirm it in the light of the available evidence. ... The second moral is that the truth may always be hidden, and may indeed have been hidden on purpose, which the result that the controversy, as Ad Herennium says, 'will be about what in fact took place. ${ }^{20}$

Skinner compares the resolution of the conjectural questions to detective work. ${ }^{21}$ Rhetoricians realise that interpretative conjectures remain hypothetical and must be debated pro et contra. Skinner also sees that historical interpretations might be connected to different interests and power shares.

Conjectural questions remain at the core of disputes between historians. The rhetorical tradition, including Max Weber, ${ }^{22}$ emphasise that being dependent on opposed perspectives, the 'facts' look different in each of them. Then the questions of 'evidence' are tools to argue for or against competing conjectures, making some of them sound more plausible than others, but without arriving to a definite conclusion. When Skinner regards scholarly work as part of an ongoing debate, ${ }^{23}$ this also means that a final verdict analogous to that of a judge cannot be expected. On the contrary, a reopening of past debates that were thought to having been closed is a major achievement for a historian.

The conjectural aspects of interpretation of the present and prospective future situations does not concern the 'facts', because they are either have not yet been established or may change at any moment. Matters of dispute concern interpretations of what can and cannot be done in a given situation, including the chances regarding how and by what means a situation can be altered and what are their conceivable and expected consequences. 
In applications the 'conjectural' questions include interpretations of the past, the present and the future. The description of the 'state of the art' serves as the background for discussing the present and the future. For the justification of the applications the judgment of the currently available of chances is relevant, as a provocative moment of journalistic of simplification of the present, which accentuates the application's distinct point and profile. For the judgment of a committee, such controversial moment, might, however, mean a 'high risk' factor, but perhaps worth a try.

A research plan as such is, of course, of conjectural character. How can we judge the applicant's account for the future scholarly operations, the rhetorical steps faced by the intended research, the ideal typical alternatives to deal with them as well as for a preliminary presentation and justification of the choices to be made at each step? The first criterion is, whether the research plan is operational enough in order to be plausible at all. The second question concerns the narrative and justification of the operations planned to be done: does the scholar manifest her professional competence of in identifying the knot-points of research process as such, set in relation to the mastery of the topic, knowledge of the sources and so on. To judge such questions requires, however, that the evaluators are competent scholars to assess that specific kind of research.

The art of posing 'conjectural questions' corresponds to Weber's insistence that in scholarly controversies there are no common 'questions and research areas' (Fragen und Gebiete) but what are questions worth studying are themselves subject scholarly disputes. ${ }^{24}$ Like in parliament, also in scholarly disputes the agenda-setting itself, not only items already on the agenda, is increasingly at the state of the disputes. In judging the agenda controversies, perhaps the situational diagnosis of the present is even more important than the plans for following its inspiration in the definite future-oriented research agenda.

\section{Second-order debate between the rhetorical genres}

In the rhetoric of applications there is a struggle between epideictic, forensic and deliberative interpretations on priority and on the procedure of evaluation. A common element of the rhetoric of theatre, court and parliament is that the actors' interventions form parts of the controversy, and the events themselves depend on the judgment of these interventions. Also the applications must be understood in this comparative sense. 
The evaluation by 'experts' is a version of epideictic rhetoric: to talk of the 'rhetoric of the pulpit' suits equally to the rhetoric of ex cathedra in schools and universities as to the priests it was originally used. They all are cases of the rhetoric of authority, against which the audience has no other means to object than refusing to acclaim. This was a major reason why Weber was against value declarations ex cathedra. ${ }^{25}$

When speaking of academic applications, a relative equality between the applicants and the evaluators prevails, which makes the rhetoric of pulpit model inapplicable. The standard figure of application rhetoric today is 'peer review', although the evaluators not always play in the same academic league than the applicants. This concept of 'peer review', however, contains different interpretations in the three main rhetorical genres. In the art criticism a profession of critics has risen, including a personal separation of critics from the practising artists. One possibility would then be to develop 'science criticism' as an analogy for the rhetoric of applications. I very much doubt this.

The professional academic critic should have the minimal scholarly competence in order to evaluate scholars at all. The new profession would be liable to become a refugium for second-rate scholars. The critics would be incompetent to judge advanced scholars or evaluate people with highly different research agendas. Above all, the standards of criticism are controversial and historically variable among the critics. The lesson of rhetoric as a thinking in utramque partem $^{26}$ is that to hope for a consensus on criteria is both vain and would be a sign of stagnation. ${ }^{27}$ Nonetheless, the there might be sufficient agreement in rejecting certain applications that are badly written.

It is tempting to interpret the peer review in terms of forensic rhetoric, regarding the application as a plea and the evaluation decided by a jury. This model is also of limited value. The aim of the application is not to get the adversary wrong but to present one's own research agenda. The forensic rhetoric suits to the past tense, but the applications concern the horizon of expectations. ${ }^{28}$ Nonetheless forensic criteria would be enough to exclude application containing illegal measures, fraud or unfair conduct against colleagues.

When Skinner recommends reading Leviathan like reading 'a speech in parliament, ${ }^{29}$ this refers to a deliberative view of the scholarly activity as a debate. The topic is the evaluation and assessment of the pros and cons, the comparative strengths and weaknesses of the applications. The applicants-petitioners can be treated as candidates to the republic of letters or to a better position within it, and the evaluation committee can thematise the scholarly disputes on the agenda-setting in a parliamentary-style. 
The strong proceduralism of parliamentary debates pro et contra provides a model for academic competitions. In a parliamentary petition committee, both the principles and the details of the motion are debated. The committee members rely on a generalist judgment, but specialists can be heard in the committee in order to evaluate the plausibility of the planned research operations.

In scholarly matters votes do not decide the quality of research, but among competing applications the vote is the last resort. What Weber calls the academic hazard $^{30}$ is inherent to the life of the applicants. Losing am application contests merely states that the application did not succeed in this specific competition. A thorough debate on the strengths and weaknesses of applications according to the parliamentary committee model, before resorting to vote, is as important for the evaluation process than the final vote.

The 'parliamentarisation' of the evaluation process cannot guarantee the selection of best applications. Nonetheless, the parliamentary 'fair play' can provide academic debates a deliberative model for the procedure of application. If the applicants participate in hearings and receive committee reports that comment in detail the strengths and weaknesses of their application, also those who lost the final vote would profit of the debate on their applications.

The deliberation pro et contra is the common for both parliamentary and academic debates, although only the former operates on the basis fair and regular dealing with controversies. ${ }^{31}$ The deliberative rhetoric of application could follow the parliamentary model of debate in important respects. Furthermore, the application process would then be a regular part of the research process itself.

By taking Skinner's advice seriously, applicants would profit from looking at parliamentary procedures and practices of debates. Debates on votes of confidence and the hearings in parliamentary investigation committees could be particularly valuable.

\section{Note}

\footnotetext{
${ }^{1}$ Max Weber, 'Politik als Beruf' [1919], in Max Weber, Wissenschaft als Beruf, 1917/1919; Politik als Beruf, 1919, Studienausgabe der Max Weber-Gesamtausgabe, I/17, ed. Wolfgang J. Mommsen and Wolfgang Schluchter, with the cooperation of Birgitt Morgenbrod. Tübingen: J.C.B. Mohr, 1994, 36. ${ }^{2}$ Aristotle, Rhetorik, trans. and ed. Franz G. Sievecke. Munich: Fink, 1987, 1358b-1359a.

${ }^{3}$ See esp. Weber, 'Die “Objektivität” sozialwissenschaftlicher und sozialpolitischer Erkenntnis' [1904]. In Gesammelte Aufsätze zur Wissenschaftslehre, ed. Johannes Winckelmann,. Tübingen: Mohr, 1973, 146-214; Weber, 'Parlament und Regierung in neugeordneten Deutschland' [1917], in Max Weber, Zur Politik im Weltkrieg. Schriften und Reden 1914-1918, Studienausgabe der Max Weber-Gesamtausgabe, I/15, ed. Wolfgang J. Mommsen and Gangolf Hübinger. Tübingen: J.C.B. Mohr, 1988, 202-302; see also Kari Palonen, „Objektivität” als faires Spiel. Wissenschaft als Politik bei Max Weber. Baden-Baden: Nomos, 2010.
} 
${ }^{4}$ Quentin Skinner, Forensic Shakespeare. Oxford: Oxford University Press, 2014, 18, also 68.

${ }^{5}$ Skinner, Forensic Shakespeare, 77.

${ }^{6}$ Skinner, Forensic Shakespeare, 68.

${ }^{7}$ Skinner, Forensic Shakespeare, 69.

${ }^{8}$ See Skinner, Forensic Shakespeare, 70-1.

${ }^{9}$ See Skinner, Reason and Rhetoric in the Philosophy of Hobbes. Cambridge: Cambridge University

Press, 1996, ch. 4; and Quentin, 'Paradiastole,' in Renaissance Figures of Speech, ed. Sylvia Adamson et al., Cambridge: Cambridge University Press, 2007. 147-63.

${ }^{10}$ Skinner, Forensic Shakespeare, 72.

${ }^{11}$ Skinner, Forensic Shakespeare, 73.

${ }^{12}$ Skinner, Forensic Shakespeare, 79.

${ }^{13}$ Both quotes from Skinner, Forensic Shakespeare, 105.

${ }^{14}$ Skinner, Forensic Shakespeare, 143-44.

${ }^{15}$ Skinner, Forensic Shakespeare, 145.

${ }^{16}$ Skinner, Forensic Shakespeare, 148.

${ }^{17}$ Skinner, Forensic Shakespeare, 23.

${ }^{18}$ Skinner, Forensic Shakespeare, 212-13.

${ }^{19}$ Skinner, Forensic Shakespeare, 220.

${ }^{20}$ Skinner, Forensic Shakespeare, 226-27.

${ }^{21}$ Skinner, Forensic Shakespeare, 227

${ }^{22}$ Weber, 'Objektivität,' esp. 171, 181.

${ }^{23}$ Quentin Skinner interviewed by Alan Macfarlane, 10 January 2008, http://www.dspace.cam.ac.uk/bitstream/1810/ 197060/1/skinner.txt, 2008

${ }^{24}$ Weber, 'Objektivität,' 183-84.

${ }^{25}$ Weber, 'Der Sinn der "Wertfreiheit" in soziologischen und ökonomischen Wissenschaften' [1917], in Gesammelte Aufsätze zur Wissenschaftslehre, ed. Johannes Winckelmann. Tübingen: Mohr, 1973, 489540.

${ }^{26}$ See Skinner, Reason and Rhetoric in the Philosophy of Hobbes.

${ }^{27}$ Weber, 'Objektivität,' 184.

${ }^{28}$ See Reinhart Koselleck, Vergangene Zukunft. Zur Semantik geschichtlicher Zeiten. Frankfurt am Main: Suhrkamp, 1979.

${ }^{29}$ Skinner, Interview.

${ }^{30}$ Weber, 'Wissenschaft als Beruf,' in Max Weber, Wissenschaft als Beruf, 1917/1919; Politik als Beruf, $1919,3-4,7$

${ }^{31}$ See Weber, 'Objektivität'; Palonen, „Objektivität”. 
